\title{
A Study on The Prevalence and Associated Microorganisms of Subclinical Mastitis in Buffaloes at Swat, Khyber Pakhtunkhwa
}

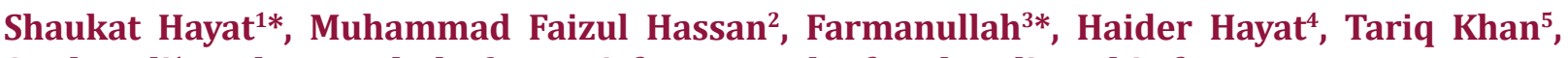 \\ Sardar Ali ${ }^{1}$, Muhammad Altaf Hussain ${ }^{3}$, Asma Babar ${ }^{3}$ and Nadia Rahim ${ }^{3}$ \\ ${ }^{1}$ Livestock \& Dairy Development Department, (Extension) Khyber Pakhtunkhwa, Pakistan \\ ${ }^{2}$ Veterinary Research \& Disease Investigation Center, Pakistan \\ ${ }^{3}$ Faculty of Veterinary and Animal Sciences, Lasbela University of Agriculture, Water and Marine, Sciences, Uthal, Pakistan \\ ${ }^{4}$ Department of Pathology, University of Veterinary and Animal Sciences, Pakistan \\ ${ }^{5}$ Department of Fisheries and Aquaculture, University of Veterinary \& Animal Sciences, Pakistan \\ *Corresponding author: Farmanullah, Faculty of Veterinary and Animal Sciences, Lasbela University of Agriculture, Water and \\ Marine Sciences, Uthal, Balochistan, Pakistan
}

\section{ARTICLE INFO}

Received: 蔧 November 14, 2020

Published: 絊 December 02, 2020

Citation: Shaukat H, Muhammad Faizul H, Farmanullah, Haider H, Tariq K, et al., A Study on The Prevalence and Associated Microorganisms of Subclinical Mastitis in Buffaloes at Swat, Khyber Pakhtunkhwa. Biomed J Sci \& Tech Res 32(2)-2020. BJSTR. MS.ID.005225.

\begin{abstract}
The present study was conducted to determine the prevalence rates and associated microorganism of the subclinical mastitis in buffaloes in Swat. Four areas were selected from collection of the data i.e. Khwazakhela, Kabal, Matta and Marghazar and 200 milk samples were collected from each site and were examined through SFMT for the presence of subclinical mastitis. The results of the study revealed that overall prevalence rates were found to be $44.5 \%$ [highest in Kabal (50.0\%), followed by Matta (48.0\%), Marghazar $(42.0 \%)$ and Khwazakhela (38.0\%)]. Out of total 800 quarters 183 were found to be infected (22.87\%). The SFMT positive samples when cultured at VR\&DIC, Balogram, Swat, revealed the isolation and identification of nine bacterial species: Staphy. aureus (35.51\%), E.coli (16.39\%), Strept. agalactea (14.75\%), Strept. dysgalactae (7.83\%), Proteus vulgaris (4.37\%), Citrobacter sp. (4.18\%), Strept. uberis (3.82\%), Bacillus cereus (3.27\%), Pseudomonas aeruginosa (1.63\%) and mixed infection $(8.25 \%)$.
\end{abstract}

Keywords: Buffaloes; Microorganisms; Prevalence; Subclinical Mastitis; Swat

\section{Introduction}

Livestock is an important sector of agriculture in Pakistan, which accounts for $50 \%$ of the agricultural value, about $11 \%$ in the total GDP, of the country. The role of livestock in rural economy can be realized from the fact that 30-35 million rural population is engaged in livestock raising, having household holdings of 2-3 cattle/buffalo and 5-6 sheep/goats per family, that help them to derive 30-40 percent of their income from it. Among the common animal diseases, mastitis is the most important infectious disease of dairy animals, causing significant financial losses worldwide and is a major cause of antibiotics use in dairy buffaloes [1]. Mastitis is the inflammation of the parenchymal cells of the mammary glands associated with microbial infections and physiological changes [2]. Mastitis has two types-clinical and subclinical mastitis. In the clinical mastitis all the five cardinal signs of inflammation can be observed while the subclinical mastitis has no obvious manifestation and thus can only be detected by the milk examination [3]. The prevalence rates of subclinical mastitis have been reported 3-40 times more than the clinical mastitis [4]. Keeping in view, its importance, the present study was conducted to determine the prevalence rates and associated microorganism of the subclinical mastitis in buffaloes in Swat. 


\section{Materials and Methods}

\section{Collection of milk Samples}

First of all, the udders were washed with tap water and dried with separate tissue papers whereas the quarters (teats) were disinfected with a piece of cotton soaked in $70 \%$ ethyl alcohol. Then 800 milk samples from 200 healthy buffaloes were collected aseptically in sterilized bijoux bottles.

\section{Surf Field Mastitis Test (SFMT)}

The routinely used Surf Field Mastitis Test (SFMT), which is based on the principle that interaction between an anionic detergent (surf) and the cationic DNA of the somatic cells present in abnormal milk results in coagulation and gel formation [5]. SFMT solution was prepared by adding 3 grams of detergent Surf Excel (Lever Brothers Pakistan) to a measuring cylinder and adding distilled water up to $100 \mathrm{ml}$ mark. An equal quantity of $3 \%$ Surf solution was added to a test sample on a plastic fabricated paddle with four rectangles for each quarter. The mixture was swirled for about one minute and then examined visually for the presence of small flocculates and/or gel which indicated presence of infection.

\section{Bacteriological Examination}

Samples from SFMT positive animals were collected in screwcapped bottle and transferred in thermal boxes containing ice packs [6] to VR\&DIC, Balogram, Swat, for further examination. Samples were incubated aerobically at $37^{\circ} \mathrm{C}$ for 24 hour and then centrifuged at 3000rpm for 20 minutes. The supernatant was discarded and a loopful from the sediment was streaked onto the surface separately on each of the following media, 5\% sheep blood agar, MacConkey's agar and nutrient agar. The plates were incubated at $37^{\circ} \mathrm{C}$ for $24-48$ hours and examined for bacterial growth. From growing colonies smears were made and stained with Gram stain. The isolated colonies were identified by their morphological characteristics, colonial appearance and then picked up, cultured on slope agar to get pure culture [7].

\section{Results and Discussion}

\section{Animal-wise Prevalence}

Table 1: Prevalence rates of subclinical mastitis in buffaloes of swat.

\begin{tabular}{|c|c|c|c|}
\hline Village & Animals Tested & $\begin{array}{c}\text { Positive } \\
\text { Animals }\end{array}$ & $\begin{array}{c}\text { Prevalence } \\
\text { (\%) }\end{array}$ \\
\hline Khwazakhela & 50 & 19 & 38 \\
\hline Kabal & 50 & 25 & 50 \\
\hline Matta & 50 & 24 & 48 \\
\hline Marghazar & 50 & 21 & 42 \\
\hline Total & 200 & 89 & 44.5 \\
\hline
\end{tabular}

The prevalence rates in four areas of Swat recorded in present study were as: Kabal 50\%, Matta 48\%, Marghazar 42\% and Khwazakhela 38\%, thus the highest prevalence was found in Kabal
(50\%) and the lowest in Khwazakhela (38\%). The overall prevalence rate was found to be $44.5 \%$ (Table 1). [95\% Confidence Interval (CI), $\mathrm{P} \pm 1.96 \sqrt{ }(\mathrm{pq} / \mathrm{n})=37.6-51.4 \%$ ] Comparison of prevalence rates among the areas through statistical analysis shows that the prevalence rates among the villages were quite comparable and did not differ significantly $\left(\chi^{2}=1.84, \mathrm{df}=3, \mathrm{P}>0\right.$, as at $\alpha$ level of 0.05 is 7.81 and at $\alpha$ level of 0.5 is 2.37 ).

\section{Quarter-wise Prevalence}

Out of total of 800 quarters (200 Buffaloes) examined, 183 were found positive for sub-clinical mastitis, and thus the overall quarterwise prevalence was recorded as $22.87 \%$ (Table 2). Quarter-wise prevalence by position was as: $\mathrm{FL}=20.0 \%, \mathrm{FR}=29.0 \%, \mathrm{HL}=10.5 \%$ and $\mathrm{HR}=32.0 \%$. and thus, varied from $10.5 \%$ to $32.0 \%$. Apparently the effect of position was quite substantial and warranted statistical analysis to evaluate the extent of variation due to position in udder. The data were, therefore, subjected to Chi Square analysis against the null hypothesis of uniform distribution of affected quarters in all the four positions in udder (Table 3). The statistical analysis shows that at degree of freedom 3 , the tabulated value of chi square at $\alpha$ level of 0.001 is $=16.27$, hence the quarter-wise prevalence rates of sub-clinical mastitis in buffaloes were not the same for all the four positions, but significantly differed from one position to another. Not all the four quarters ran the same risk of getting the sub-clinical mastitis $\left(\chi^{2}=24.67, \mathrm{df}=3, \mathrm{P}<0.001\right)$.

Table 2: Quarter-wise prevalence of Sub-Clinical Mastitis.

\begin{tabular}{|c|c|c|c|}
\hline Position & Left Side & Right Side & Total \\
\hline Front Position & FL 40/200 & FR 58/200 & $98 / 400$ \\
\hline Hind Position & HL21/200 & HR 64/200 & $85 / 400$ \\
\hline Total & $61 / 400$ & $122 / 400$ & $183 / 800$ \\
\hline
\end{tabular}

Table 3: Test for uniformity of distribution with respect to Position.

\begin{tabular}{|c|c|c|c|}
\hline Position & $\begin{array}{c}\text { Observed affected } \\
\text { quarters }\end{array}$ & $\begin{array}{c}\text { Expected } \\
\text { affected quarters }\end{array}$ & $\chi^{\mathbf{2}}$ \\
\hline Front Left (FL) & 40 & 45.75 & 0.723 \\
\hline Front Right (FR) & 58 & 45.75 & 3.28 \\
\hline Hind Left (HL) & 21 & 45.75 & 13.389 \\
\hline Hind Right (HR) & 64 & 45.75 & 7.28 \\
\hline Total & 183 & 183 & 24.672 \\
\hline
\end{tabular}

Naturally it was of interest to analyze whether quarters of front position differ from those of the hind position with respect to prevalence of sub-clinical mastitis. Similarly it was also of interest to know whether quarters on right side differ from those on left side with respect to risk of the disease. Data on these two aspects have been set out in (Tables $4 \& 5$ ) and subjected to Chi Square analysis. The statistical analysis shows that at degree of freedom 1 , the tabulated value of chi square at $\alpha$ level of 0.05 is 3.84 , hence the prevalence rates of sub-clinical mastitis in front and hind quarters of buffaloes did not differ significantly $\left(\chi^{2}=1.198, \mathrm{df}=1, \mathrm{P}>0.05\right)$. 
(Table 5) Comparison of Prevalence between Left and Right side (Figures in Parenthesis are expected frequencies on basis of Null hypothesis). The statistical analysis shows that at degree of freedom 1 , the tabulated value of chi square at $\alpha$ level of 0.05 is 3.84 and at $\alpha$ level of 0.010 is 6.63; hence the prevalence rates of subclinical mastitis in left and right side quarters of buffaloes differ significantly. Quarters on the right side of the animal were at higher risk of getting the disease $\left(\chi^{2}=8.27, \mathrm{df}=1, \mathrm{P}<0.01\right)$.

Table 4: Comparison of front and hind position quarters of buffaloes (Figures in Parenthesis Are frequencies expected on the basis of Null hypothesis).

\begin{tabular}{|c|c|c|c|}
\hline Samples status & Front position & Hind position & Total \\
\hline Positive & $98(91.5)$ & $85(91.5)$ & 183 \\
\hline Negative & $302(308.5)$ & $315(308.5)$ & 617 \\
\hline & 400 & 400 & 800 \\
\hline
\end{tabular}

Table 5: Comparison of Prevalence between Left and Right side (Figures in Parenthesis are expected frequencies on basis of Null hypothesis).

\begin{tabular}{|c|c|c|c|}
\hline Samples status & Left side & Right side & Total \\
\hline Positive & $62(101.5)$ & $122(101.5)$ & 183 \\
\hline Negative & $319(298.5)$ & $278(298.5)$ & 597 \\
\hline----- & 400 & 400 & 800 \\
\hline
\end{tabular}

\section{Bacterial Spp. Associated with Subclinical Mastitis}

Table 6: Bacterial Species Isolated from SFMT Positive Samples $(\mathrm{N}=183)$.

\begin{tabular}{|c|c|c|}
\hline Name of bacterial Specie & No of Samples & \% age \\
\hline Staphy Aureus & 65 & 35.51 \\
\hline E.cloi & 30 & 16.39 \\
\hline Strept. Agalactiae & 27 & 14.75 \\
\hline Strept. Dysgalactiae & 17 & 7.83 \\
\hline Proteus vulgaris & 8 & 4.37 \\
\hline Strept. Uberis & 7 & 3.82 \\
\hline Bacillus cereus & 6 & 3.27 \\
\hline Citrobacter sp. & 4 & 2.18 \\
\hline Pseudomonas aeruginosa & 3 & 1.63 \\
\hline Mixed (Staph. aureus \& E.coli) & 10 & 5.46 \\
\hline Samples with no growth & 6 & 3.27 \\
\hline Total & 183 & 100 \\
\hline
\end{tabular}

The true positive 183 samples when cultured revealed nine bacterial species involved which are: Staph. aureus in 65 (35.51\%), E.coli in 30 (16.39\%), Strept. Agalactea in 27 (14.75\%), Strept. dysgalactiae in 17 (7.83\%), Proteus vulgaris in 08 (4.37), Citrobacter sp. in 04 (4.18\%), Strept. uberis in 07 (3.82\%), Bacillus cereus in $06(3.27 \%)$ and Pseudomonas aeruginosa in 03 (1.63\%) samples. In addition to individual infections mixed infections caused by Staphy. aureus and E. coli were observed in 10 (5.46\%) samples. No bacterial growth in 06 (3.27\%) samples, although they were found positive for sub-clinical mastitis through SFMT
(Table 6). The overall prevalence rate $(44.5 \%)$ and quarter-wise prevalence $(22.87 \%)$ has some resemblances with the results of [8] results (36.67\% CMT) and [9] results at Attock (quarter-wise $12.08 \%$ and animal-wise $44 \%$ ) [10] results regarding bacterial species (Staph. aureus 21.3 \%, E.coli 15.9 \%, Strept. dysgalactiae $15.6 \%$, Strept. uberis $11.1 \%$, coagulase-negative staphylococci $6.2 \%$, Arcanobacterium pyogenes $6.1 \%$ and Klebsiella species $4.2 \%$ and results (Staph. aureus $31.03 \%$, E. coli $24.31 \%$, Strept. agalactiae $10.34 \%$, Strept. dysgalactiae $10.34 \%$, Bacillus cereus $10.32 \%$ and Strept. pyogenes $6.89 \%$ ) also support the results of the present study to a greater extent.

\section{Conclusion}

The present study indicates that subclinical mastitis in buffaloes $(44.50 \%)$ is a major problem and threat to the livestock farmers of the swat. The probable reasons might be the poor manage mental practices adopted by the farmers and thus warrant immediate but sustainable attention. The disease control is possible through improving husbandry techniques, milking hygiene, adapting of dry cow therapy (sealing of the teats by acrylic lates at the time of drying off) and early diagnosis through SFMT and treatment of the disease.

\section{Acknowledgements}

I express sincere thanks to our Research Team/Group for their kind collaboration and assistance. Special thanks to all of them for their supervision and guidance. I am also very appreciative to the co-authors for their critical and technical improvement of our manuscript.

\section{Authors' Contributions}

S.H and M.F.H wrote the original draft of the manuscript. S.H, M.F.H, and H.H conceived and designed the experiment. T.K, F and S.A helped in data collection and management. M.A.H, and F. helped in data analysis.

\section{Conflict of Interest}

The authors declare that there are no conflicts of interest regarding the publication of this paper.

\section{References}

1. Mitchell JM, Griffiths MW, McEwen SA, Menab WB, Yee AJ, et al. (1998) Antimicrobial drug residues in milk and meat: Causes, concerns, prevalence, regulations, tests and test performance. J Food Protect 61: 742-756.

2. Radostitis OM, Blood DC, Gray CC (1996) Veterinary Medicine. $8^{\text {th }}$ Edn. Billiere Tindall, London pp. 563-614.

3. Hillerton JE (1999) Balancing mastitis and quality. Proc. British Mastitis Conference, Stonelergh, UK. pp. 1-7.

4. Schultz LH, Brown RW, Jasper DE, Natzke P (1978) Current Concepts of Bovine Mastitis. The National Mastitis Council, Inc. Washington DC USA $2^{\text {nd }}$ edn pp. 6-9. 
5. Thiers FO, Benites NR, Costa EO (1999) Correlação sentre contagem direta de células somáticas e o teste de Califórnia Mastitis Test (CMT) no leite de vacas. Napgama 2(4): 9-12.

6. Gabbar MAK (1992) Manual for field veterinarians on dispatch of specimens for laboratory diagnosis. Field document No 3, $2^{\text {nd }}$ Edn. Central Veterinary Diagnostic Laboratory, Tandojam, Sindh, Pakistan.

7. Holt JG, Krieg NR, Sneath PHA, Stanley JT, William ST (1994) Bergey's Manual of determinative Bacteriology. $9^{\text {th }}$ edn, William and Wilkins, Baltinmore, Maryland.

ISSN: 2574-1241

DOI: $10.26717 /$ BJSTR.2020.32.005225

Shaukat Hayat, Farmanullah. Biomed J Sci \& Tech Res

(C) This work is licensed under Creative Commons Attribution 4.0 License

Submission Link: https://biomedres.us/submit-manuscript.php
8. Hunderra S, Ademe Z, Sintayehu S (2005) Dairy buffaloesmastitis in and around Sebeta, Ethiopia. J Dairy Sci 56(2): 109-115.

9. Bachaya HA, Iqbal Z, Muhammad G, Yousaf A (2005) Sub-clinical mastitis in buffaloes in Attock District of Punjab (Pakistan). Pak Vet J 1 25(3): 134136.

10. Ericsson UH (2009) Microbial aetiology of acute clinical mastitis and agent-specific risk factors. Vet. Microbiol 137 (1-2): 90-97.

$\begin{array}{ll}\text { BIOMEDICAL } & \text { Assets of Publishing with us } \\ \text { RESEARCHES } & \text { - Global archiving of articles } \\ & \text { - Immediate, unrestricted online access } \\ & \text { - Rigorous Peer Review Process } \\ & \text { - Authors Retain Copyrights } \\ \end{array}$

